\title{
Briefly: the Maldive Islands
}

François Moutou

The author made a brief visit to the Maldive Islands in 1984. These beautiful coral atolls are being rapidly developed for tourism and there is an urgent need to achieve a balance between the attendant changes and wildlife conservation.

The Maldives, a $750-\mathrm{km}-$ long archipelago of some 1500 coral islands in the Indian Ocean, were once remote. Nowadays, air travel has brought them within easy reach of an increasing number of tourists from Western Europe, attracted by the sun and the white sands of the beaches. Only 200 of the islands are inhabited by fishermen, but tourist resorts are rapidly being built on uninhabited islands, bringing much disturbance to their wildlife.

In addition to the kind of destruction that building brings, wildlife also suffers from other aspects of tourism. Marine turtles are protected by law, but they are sold everywhere, either stuffed or as shells. There seems to be no problem in leaving the airport with one. The hawksbill turtle Eretmochelys imbricata suffers most of the trade. In every shop in Male, the 'capital' island, and in many village houses, one can buy large quantities of sea shells. The trade in cowries, in particular Cypraea moneta, is enormous; they are sold by the thousands to India for jewellery. It must be difficult to estimate the levels of capture that these species can sustain, but the exercise should be attempted before it is too late.

The Maldive Islands are well known for the marine life of their beautiful lagoons and coral reefs. The terrestrial life is fascinating too. Traditionally, the Maldivian populations of flora 232 and fauna were considered to be only geographical extensions of equivalent Singhalese or Indian populations. More detailed studies in recent years lead us to believe that the degree of endemicity is more important than was previously accepted, and that evolution of new forms is still proceeding on the 100,000-year-old archipelago.

The vegetation is typical of Indo-Pacific coasts. Screw-pines Pandanus spp. thrive particularly well, and there are five endemic species (Fosberg, 1957; Adams, 1983). The few areas of mangrove swamp are rich in Rhizophora spp., and on islands as yet uninhabited, or untouched by tourism, there are still beautiful tropical forests, even though they cover only a few hectares and grow no more than 5 or $6 \mathrm{~m}$ tall. Elsewhere, coconut palms predominate. Fruit trees have been established on the inhabited islands, while decorative flowering trees have been planted on the tourist islands.

There are only two native mammals, both fruit bats (Hill, 1958). Pteropus giganteus ariel is not too hard to find, even if it does not seem as numerous as in former accounts. $P$. hypomelanus maris is known only from Addu atoll, the most southerly, and has been seen only once. The black rat Rattus rattus and the musk shrew Suncus murinus have been introduced by human agency, as has the house mouse Mus musculus, although this is less common than the former two species. Domestic animals are very few and limited to a few cats and goats; dogs are forbidden on religious and health grounds.

More than 100 species of birds have been Oryx Vol 19 No 4 


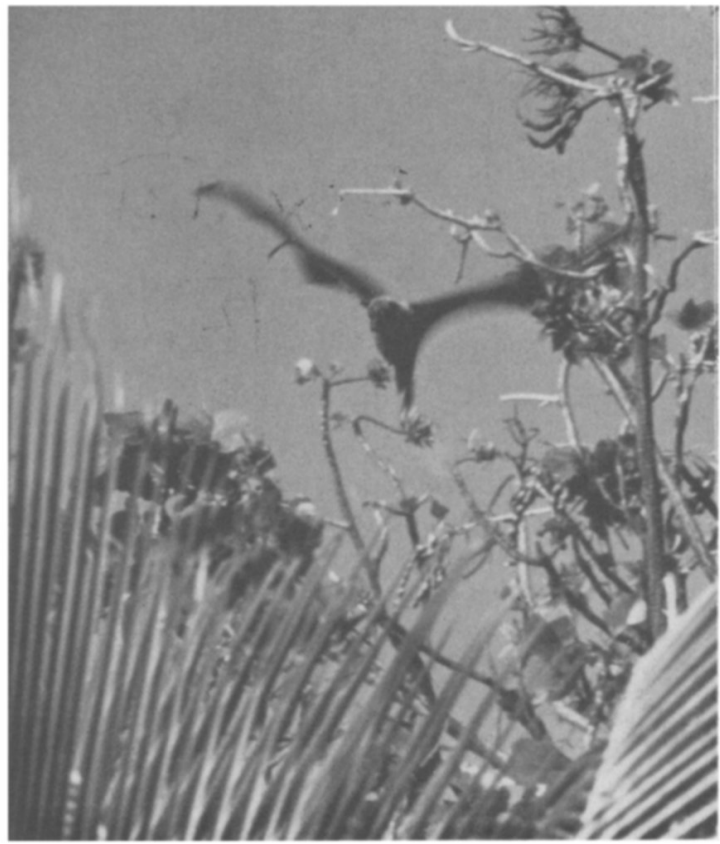

Above: Fruit bat Pteropus giganteus ariel (F. Moutou).

Right, top: Cowries are sold by the thousands (F. Moutou).

Right, bottom: Hawksbill turtles are sold everywhere, stuffed or as shells, despite legal protection (F. Moutou).

reported from the Islands, most of them migrants. The residents include the house crow Corvus splendens maledivicus and its cuckoo-parasite, the koel Eudynamys scolopacea (Phillips, 1963). It is interesting to imagine how these two met here. Grey herons Ardea cinerea and striated herons Butorides striatus are common everywhere. On the island of Lhosfushi (South Male atoll) I saw a kingfisher, possibly Alcedo atthis, a species not mentioned in the scarce literature on these islands.

The reptiles are all introduced, probably from Sri Lanka: two nocturnal house geckos of the genus Hemidactylus; the common garden lizard or bloodsucker Calotes versicolor; the snake skink Riopa albopunctata; and the common wolf snake Lycodon aulicus (Phillips, 1958).

The Maldive Islands, like other oceanic islands, are fragile. Agricultural development is replacing the natural vegetation on some islands, and coral reefs are being exploited for new buildings. There is a need for active conservation measures now. The trade in shells and turtles cannot continue at The Maldive Islands
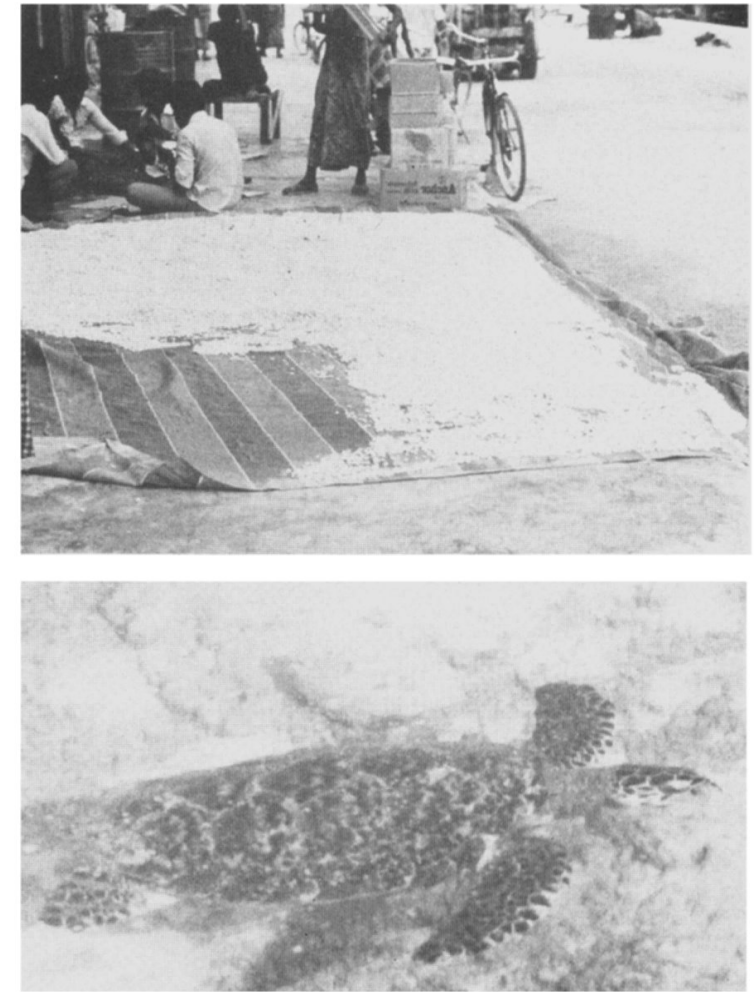

the present rate, the collection of eggs from seabird colonies must be controlled, and some islands should be left intact. Tourism is becoming one of the most prosperous industries in this young republic, but it would be a shame if its growth was to be accomplished to the detriment of the environment.

\section{References}

Adams, C.D. 1983. Report to the Govemment of the Maldive Islands on Flora Identification. FAO Manuscript, $41 \mathrm{pp}$.

Fosberg, F.R. 1957. The Maldive Islands Indian Ocean. Atoll Research Bulletin, 58, 1-37.

Hill, J.E. 1958. Some observations on the fauna of the Maldive Islands. 2. Mammals. J. Bombay Nat. Hist. Soc. $\mathbf{5 5}(1), 3-10$.

Phillips, W.W.A. 1958. Some observations on the fauna of the Maldive Islands. 4. Amphibians and Reptiles. J. Bombay Nat. Hist. Soc. 55(2), 217-220.

Phillips, W.W.A. 1963. The birds of the Maldive Islands Indian Ocean. J. Bombay Nat. Hist. Soc. 60 (3), 546-584.

Reptile nomenclature follows: Daniel, J.C. 1983. The Book of Indian Reptiles, Bombay Natural History Society, Bombay, India.

François Moutou, 22 rue Mouffetard, 75005 Paris, France. 